\title{
WeChat as a Lifestyle: Social Network Tool of the Chinese Migrants in Russia
}

\author{
Yuliya O. Koreshkova* \\ Irkutsk State University \\ 1 Karl Marx Str., Irkutsk, 664003, Russia
}

Received 02.03.2018, received in revised form 24.10.2018, accepted 07.11.2018

In the article the author made an attempt to find out which familiar ways of interaction and daily practices are carried out by Chinese migrants using the WeChat messenger. The corpus of empirical data was interviews with Chinese workers living in the territory of the Irkutsk region. Based on these interviews, we can talk about maintaining communication in all three spheres of the Chinese society identified by V.V. Maliavin, as well as about some of the daily practices that are implemented with the help of this messenger. When using WeChat, the Chinese who live overseas manage to maintain and build new connections with the inhabitants of the Middle Kingdom, as well as with the residents of their region of residence.

Keywords: Chinese migrants, social connections, daily practices, WeChat.

The article was written with the financial support of the Russian Foundation for Basic Research in the framework of the research project No. 16-03-00100 "Ethnic markets" in space of a postSoviet Siberian city."

Research area: sociology.

Citation: Koreshkova, Iu.O. (2018). WeChat as a lifestyle: social network tool of the Chinese migrants in Russia. J. Sib. Fed. Univ. Humanit. soc. sci., 11(11), 1816-1823. DOI: 10.17516/1997-1370-0342.

The most important task of a trans-boundary migrant is adaptation in the host society. As a rule, it is solved through the use of a network of social connections and obligations - either brought from the country of origin or formed in the host country. These networks are also necessary to meet cultural and social needs, to maintain at least elements of their usual way of life, and to maintain links with their historic homeland. Forms and mechanisms for the formation of such networks and maintaining them in a working form have been established for centuries of migration practices. However,

(C) Siberian Federal University. All rights reserved

* Corresponding author E-mail address: yuliakodzhaeva@yandex.ru

This work is licensed under a Creative Commons Attribution-NonCommercial 4.0 International License (CC BY-NC 4.0). 
the revolutionary changes in the field of information technology led to the formation of a phenomenon that was called transnationalism. Internet tools allowed forming social networks and using them to meet immediate migrant needs without direct physical contact and direct interaction of participants.

For the Chinese, especially migrants, the WeChat messenger has become one of such tools. It introduced such radical changes in the business practices and everyday life of Chinese migrants, that one can speak of qualitatively new mechanisms for the functioning of diaspora life. This illustrates, for example, a huge response among the Chinese population of the Irkutsk region in May 2017, when Roskomnadzor banned the use of the largest Chinese messenger in the Russian Federation (RBC, 2017). In the group and individual chats one could find the following messages: "Are you online?", "Please, reply if you received a message from me?" Such messages were accompanied by links to news sites that featured information about blocking (RBC, 2017). These events made us think about the role of the messenger in the life of Chinese migrants, and we tried to find out what methods of interaction and everyday practices that are familiar to the Chinese can be implemented with its help. The corpus of empirical data was interviews with Chinese workers living in the territory of the Irkutsk region, as well as personal experience of using the messenger.

In the modern world, even people from the street can answer the question: "What are social networks?" A modern person immediately comes up with an image of interactive multi-user content that he most likely is a participant of. However, the concept of social networks that was for the first time defined by G. Simmel appeared in the scientific community long before the Internet was invented. Many Western scientists (such as M. Weber, T. Parsons, G. Mead, H. Blumer, G. Homans and others) have devoted their research to social relations. Their research works were carried out within the framework of the Western community and based on the study of its experience. Their conclusions, therefore, cannot be directly extrapolated to the Chinese social networks, since there are social, cultural, linguistic and ethnic features of the peoples of Asia.

When studying social relations in China, it is necessary to take into account the powerful tradition, in which informal relations, especially such a phenomenon of the Chinese society as "guanxi", come to the fore. "In the broad sense of the word, the term "guanxi" means interpersonal connections and a prolonged exchange of courtesies. It is more than friendship or a simple relationship, since, being in "guanxi", an individual cannot refuse to help another person from his network of contacts. "Guanxi" help to solve various issues and conflicts without resorting to official institutions of government. 
One of the distinguishing features of "guanxi" is that they, to a greater degree, are built on the basis of common institutions - kinship, place of birth, place of study or work, etc. They are one of the features of the Chinese sociocultural tradition that has been formed over the centuries and still has not lost its significance" (Veselova, 2016).

According to V.V. Maliavin, the Chinese society includes three spheres of relations: a core represented by a family; an average sphere that forms professional, business and even personal connections; and the third sphere is a circle of strangers. The core or the inner sphere is a natural life collective, first of all, a family. Here, everyone gives as much as they can, and whenever they can, without expecting any reward. But each of the givers knows that he can always count on the help and support of the family. The middle sphere is formed by stable connections of a business or friendly nature, in which relations are built on the basis of mutual benefits. In the Chinese society, reliability of connections and trust are valued especially highly. The Chinese see in friends, colleagues, partners and acquaintances their own journey: their own acquisitions, hardships, resilience in the outside world. Finally, the third, the external sphere is a circle of unfamiliar and strange people. In relation to these people, there are no personal obligations arising from consanguinity or reciprocity in relationships, which means there can be no relationship with them, and it is not necessary to turn to the "human feeling" (ren qing) that is a genuine core of the Chinese sociality. This is not about sentimental sympathy or even ordinary cordiality, but about obligations to partners in established "connections" that are quite dispassionately built on the basis of the services provided to each other" (Maliavin, 2007).

Chinese migrants have a strongly developed sense of homeland and belonging to the people and culture of their country. The phenomenon of Chinatown, as a "result of the natural desire to live in a familiar environment" (Diatlov, 2008), demonstrates how important it is to keep the usual forms of communication in the life of Chinese immigrants abroad. Until recently, it was considered obvious that this task could only be accomplished through a direct and personal contact.

With the massive use of the Internet, it has become much easier to maintain communication and save its forms; messengers, social networks and various kinds of content have become tools for this. Among Chinese migrants, the most popular messenger is WeChat, known in Chinese as 微信 (Weixin), which means “micro letter." Based on a diagram of three spheres of communication proposed by V.V. Maliavin, we can see the influence of the messenger on creating new form and maintaining old forms of social contacts among the Chinese migrants. 
With the help of WeChat, the Chinese migrants create new connections and at the same time maintain the old ones:

1) with residents of China;

2) with residents of the region they currently live in (in our case, Irkutsk region);

3) with residents of other countries and regions.

In the article, we study the first two directions

When a resident of China moves to another country, the spheres of communication are conditionally split (Fig. 1): connections and contacts remain in China, and new ones have to be made at the place of residence. As we can see in Fig. 1, before the appearance of instant messengers, well-established ties with inhabitants of the homeland gradually weakened; with the help of letters and phone calls it was possible to maintain contacts with relatives, but the second and the third spheres of communication could disappear altogether. According to one of our respondents: "Once upon a time, the Chinese brought satellite dishes with tuned Chinese TV channels from China in order to keep in touch with home in another country." The situation in the region of residence is different - the Chinese migrants manage to strengthen ties at two external levels.

However, with the ability to use the messenger, the situation has changed. Communication in it has formed a new, virtual reality where it is possible to maintain strong ties in China and in the region of residence (Fig. 2). Let us try to illustrate this idea applying to each sphere of communication.

At the first level, the tools are group chats, personal contacts, exchange of text and photo messages, as well as video chat. "It should be noted that group chats are gaining increasing popularity among social network users" (Qiu, 2016). It is not surprising, because the Chinese in the minds of Western people always seem to be noisy groups

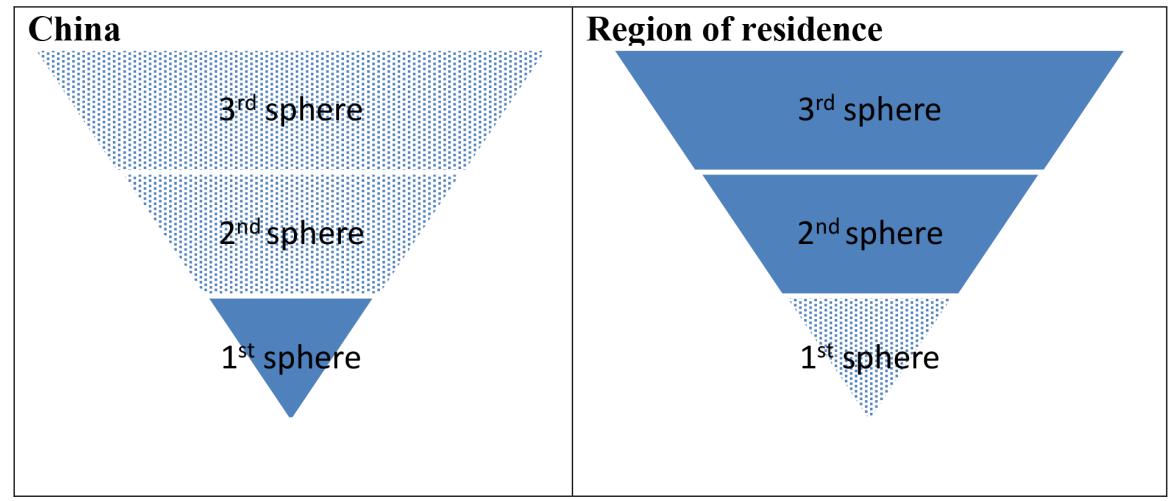

Fig. 1. Spheres of communication among migrants before using WeChat 


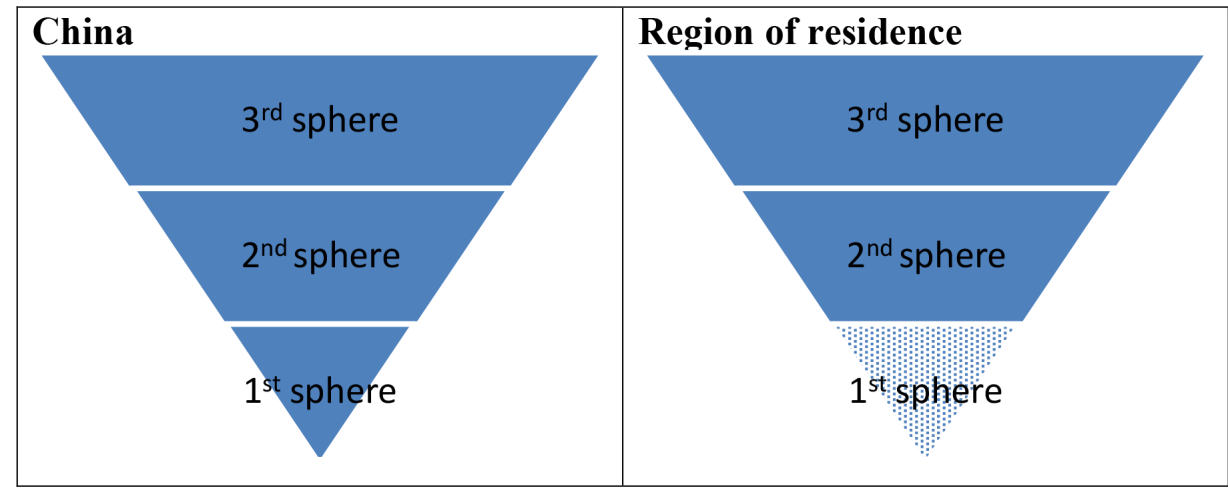

Fig. 2. Sphere of communication of Chinese migrants when using WeChat

or companies, "they always love to be with people and do not tolerate loneliness" (Speshnev, 2011). In family chats, they share news, discuss daily affairs, joke - it gives them an opportunity to stay in a familiar environment. If we are talking about the Chinese living abroad, it gives a feeling of unity with a family, does not allow them to break away from the usual way of life.

During an interview with a woman who works in Irkutsk and left her son with her parents in China, it turned out that WeChat is everything for her. She and her son do their homework through video chat, have lunch and dinner with their family, discuss the news of the day, and this helps her stay involved in the life of her son and her family. When asked if this is hindering her from adapting to local life, she replied that it is not, but on the contrary, it morally supports her, and she can no longer imagine life without a phone and this application. As we can see, the first sphere of communication is almost impossible to be formed at the place of residence, since most of the family, as a rule, remains in China. For the Chinese, "a family is our heart, those people whose pain I feel inside even if we are far from each other" (Tikhomirova, Zhao, 2012). WeChat virtually allows you to maintain close daily contacts with your family.

At the second level of communication, when using WeChat, it is also possible to maintain contacts with colleagues and friends in China and the region of residence (Irkutsk Region). Popular functions in this sphere are group chats and "Moments" (in Chinese translation - "friend circles"). During interviews among Chinese WeChat users in Irkutsk, we found group chats of students living and studying in Irkutsk, as well as groups of people involved in trade. Unfortunately, it was not possible to become a member of these groups, since they are closed-type chat rooms that require invitation from people who are already in these groups. However, we managed to clarify the subjects of discussions of these groups. In chat rooms associated with trade, it is usually 
transportation of goods from China and to China, as well as their resale. Members of these groups are the Chinese living both in the territory of the Irkutsk region and in the PRC. In addition, we already mentioned Moments news feed that allows you to follow the life of your friends, publish information about the events of your life, and use the resource as an advertisement, which Chinese migrants are actively using. There you can find posts ranging from advertising bags, with a single resale of American-made goods, to wholesale sales of tea, electronic products and much more. The words of one of the Chinese interviewed by us: "I post information about the goods in "Moments", and instantly receive an order in personal messages. There are orders from both China and Russia, very convenient. Since recently, you can also pay in WeChat."

WeChat has a powerful influence on the formation and preservation of relations, since before its invention the main tool for maintaining "guanxi" was a personal meeting. As a rule, it was an invitation to lunch or dinner, which of course is impossible to implement if living in another country. Joint meal still is the main attribute of establishing contacts among the Chinese, but many prefer to solve issues in the virtual space, in particular using WeChat, which enables the Chinese from abroad to do business with residents of China.

At the third level of communication, WeChat helps not only to maintain existing connections, but also to form the new ones. "Shake", "Users in the Neighbourhood", "Floating Bottle" are functions that allow you to add new unfamiliar users to your contacts. The most popular among Chinese users in the Irkutsk region is "Users in the Neighbourhood." A screen displays a list of people who are nearby. The Chinese, who arrived recently in Irkutsk, often ask those who have been here for a long time questions. They ask to suggest: where there are good shops, where you can see a doctor, how you can spend time on weekends, how to order a taxi, etc. All questions resonate with those who live here for a long time, but the third circle, as a rule, does not move into the second, the communication either remains virtual or comes to an end altogether.

Based on the above said, it is possible to talk about the users' preservation of communication in all three spheres identified by V.V. Maliavin. When using this messenger, the Chinese from abroad manage to maintain ties with the inhabitants of the Middle Kingdom, as well as with the residents of their region of residence, which seemed unthinkable a few decades ago. After conducting this study, many new questions and reasons for discussion arose. Is it possible to assume that social networks allow the community to isolate itself, to create a kind of virtual enclaves, when living 
in a mixed urban environment? Howard Rheingold's "Virtual Community" comes to mind. What new reality are social networks leading us to? What will be the new way of life, the way of life - WeChat?

\section{References}

Che, Hui Lien, Yang, Cao. (2014). Examining WeChat users' motivations, trust, attitudes, and positive word-of-mouth: Evidence from China. Che Hui Lien, Yang Cao. Computers in Human Behavior, 104-111.

Diatlov, V.I. (2008). Chainatauny v sovremennoi Rossii. Neskol'ko predvaritel'nykh zamechanii redaktora-sostavitelia [Chinatowns in modern Russia. A few preliminary remarks by the editor]. In Etnograficheskoe obozrenie [Ethnographic Review], (4), 3-5.

Kolozaridi, P.V., Il’in, A.V. (2016). Messendzhery v gorodskoi srede: gibridnye formy i novye praktiki [Tekst]. Messengers in the urban environment: hybrid forms and new practices [Text]. In Shagi-Steps. 2 (1), 127-138.

Maliavin, V.V. (2007). Kitai upravliaemyi. Staryi dobryi menedzhment [China managed. Good old management]. Moscow, "Evropa", 306 p.

Maslov, A.A. (2010). Nabliudaia za kitaitsami. Skrytye pravila podeveniia [Watching the Chinese. Hidden rules of behavior]. Moscow, RIPOL Classic, 288 p.

Qiu, J. (2016). The Lifecycle and Cascade of WeChat Social Messaging Groups. Jiezhong Qiuy, Yixuan Li, Jie Tangy, Zheng Luz, Hao Yez, Bo Chenz, Qiang Yang and John E. Hopcroft. Department of Computer Science and Technology, Tsinghua. Available at: http://dx.doi.org/10.1145/2872427.2882979

RBC (2017). Roskomnadzor blocked the WeChat website. RBC, Technologies and Media. May 5, 2017. Available at: http://www.rbc.ru/technology_and_ media/05/05/2017/590c3e579a7947510ce825c1

Speshnev, N.A. (2011). Kitaitsy: osobennosti natsional'noi psikhologii [The Chinese: Peculiarities of National Psychology]. Saint Petersburg, KARO, 336 p.

Tikhomirova, E.E, Zhao, Ts. (2012). Kul'turnye universialii i kontsept “domsem'ia" [Cultural universals and the concept of "home-family"]. In Vestnik NGPU [Bulletin of NSPU], 2 (6), 73-79. Available at: https://cyberleninka.ru/article/n/ kulturnye-universalii-i-kontsept-dom-semya

Veselova, L.S. (2016). Institut “guan'si” v sotsial'noi i kul'turnoi istorii KNR: dissertatsiia ... kandidata istoricheskikh nauk: 07.00.03. The Guanxi Institute in the Social and Cultural History of the People's Republic of China: dissertation ... for the PhD in Historical Sciences: 07.00.03; [Place of defence: Federal State Budgetary 
Institution of Higher Education "Kazan (Volga Region) Federal University"]. Kazan, $192 \mathrm{p}$.

WeChat [微信]. Available at: http://weixin.qq.com/

\author{
«WeChat как образ жизни»: \\ инструмент социальных связей \\ китайских мигрантов в России
}

Ю.О. Корешкова

Иркутский государственный университет

Россия, 664003, Иркутск, ул. Карла Маркса, 1

Сделана попытка выяснить, какие привычные способы взаимодействия и повседневные практики осуществляются китайскими мигрантами с помощью мессенджера WeChat. Корпусом эмпирических данньх послужили интервью с китайцами, работающими и проживающими на территории Иркутской области. На основании этих интервью можно говорить о сохранении общения во всех трех сферах китайского социчма, выделенных В.В. Малявиным, а также о некоторых повседневных практиках, которые реализуются с помощью данного мессенджера. При использовании WeChat китайцам за рубежом удается поддерживать и создавать новые связи с жителями Поднебесной, а также с жителями их региона проживания.

Ключевые слова: китайские мигранты, социальные связи, повседневные практики, WeChat.

Работа выполнена при финансовой поддержке РФФИ в рамках научного проекта № 16-03-00100 «Этнические рынки» в пространстве постсоветского сибирского города».

Научная специальность: 22.00.00 - сочиология. 